\title{
Adoptive transfer of Th1-conditioned lymphocytes promotes axonal remodeling and functional recovery after spinal cord injury
}

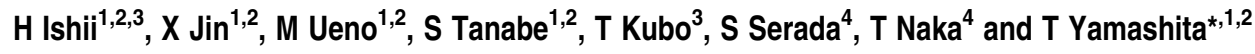

The role of T lymphocytes in central nervous system (CNS) injuries is controversial, with inconsistent results reported concerning the effects of T-lymphocyte transfer on spinal cord injury (SCl). Here, we demonstrate that a specific T-lymphocyte subset enhances functional recovery after contusion $\mathrm{SCl}$ in mice. Intraperitoneal adoptive transfer of type 1 helper $\mathrm{T}$ (Th1)-conditioned cells 4 days after SCl promoted recovery of locomotor activity and tactile sensation and concomitantly induced regrowth of corticospinal tract and serotonergic fibers. However, neither type 2 helper T (Th2)- nor IL-17-producing helper T (Th17)-conditioned cells had such effects. Activation of microglia and macrophages were observed in the spinal cords of Th1-transfered mice after SCl. Specifically, M2 subtype of microglia/macrophages was upregulated after Th1 cell transfer. Neutralization of interleukin 10 secreted by Th1-conditioned cells significantly attenuated the beneficial effects by Th1-conditioned lymphocytes after SCl. We also found that Th1-conditioned lymphocytes secreted significantly higher levels of neurotrophic factor, neurotrophin 3 (NT-3), than Th2- or Th17-conditioned cells. Thus, adoptive transfer of pro-inflammatory Th1-conditioned cells has neuroprotective effects after $\mathrm{SCl}$, with prospective implications in immunomodulatory treatment of CNS injury.

Cell Death and Disease (2012) 3, e363; doi:10.1038/cddis.2012.106; published online 9 August 2012

Subject Category: Neuroscience

Immune reactions following central nervous system (CNS) trauma such as spinal cord injury (SCl) or traumatic brain injury have been considered harmful to axonal regeneration and functional recovery. ${ }^{1-3}$ Immune cells secondarily attack even spared neurons that escape primary damage. ${ }^{1,2,4}$ However, in the last decade, the improvement of motor function by adoptive transfer or activation of autoimmune $\mathrm{T}$ cells has also been reported after CNS injury. ${ }^{5-10}$ Surprisingly, autoimmune cells originally considered pathogenic in autoimmune diseases (e.g. multiple sclerosis and rheumatoid arthritis) were indicated to be neuroprotective after CNS trauma. Furthermore, several studies have suggested that $T$ cells were beneficial to disease progression and survival after the onset of amyotrophic lateral sclerosis. ${ }^{11,12}$ In contrast, others have reported that $T$ lymphocytes caused axonal damage after CNS injury ${ }^{3,13,14}$ and that transfer of autoimmune T lymphocytes exacerbated functional recovery after $\mathrm{SCl}^{15}$ These seemingly contradictory findings may be explained by the distinct roles of each T-lymphocyte subset; some are beneficial and others are detrimental to functional recovery after CNS injuries.
For example, interleukin-17 (IL-17)-producing $\gamma \delta$ T cells were reported to have a pivotal role in the pathogenesis of ischemic brain injury. ${ }^{16}$ Thus, elucidation of the distinct role of T-cell subsets may lead to new insights for therapeutic interventions that regulate immune reaction following CNS injury.

Subsets of helper $\mathrm{T}$ cells have been suggested to have a role in the etiology of CNS diseases. IFN- $\gamma$-producing type 1 helper T (Th1) cells and IL-17-producing helper T (Th17) cells are associated with the disease onset and progression of experimental autoimmune encephalomyelitis (EAE), an animal model of multiple sclerosis. ${ }^{17}$ Shift to IL-4-producing type 2 helper T (Th2) cells was suggested to lead to enhanced functional recovery after CNS injury. ${ }^{18}$ However, knowledge of the role played by each T-lymphocyte subset is still fragmental, and the effectiveness of transferring specific T lymphocytes to treat CNS injury remains unknown. In the present study, we hypothesized that conflicting results concerning the role of $\mathrm{T}$ lymphocytes in recovery from CNS injury may be attributed to differences in the role of helper T-cell subsets, specifically that the transfer of proinflammatory Th1 cells could facilitate functional recovery

\footnotetext{
${ }^{1}$ Department of Molecular Neuroscience, Graduate School of Medicine, Osaka University, Suita, Osaka 565-0871, Japan; ${ }^{2}$ JST, CREST, Chiyoda-ku, Tokyo 102-0075, Japan; ${ }^{3}$ Department of Neurobiology, Graduate School of Medicine, Chiba University, Chuo-ku, Chiba 260-8677, Japan and ${ }^{4}$ Laboratory for Immune Signal, National Institute of Biomedical Innovation, Ibaraki, Osaka 565-0085, Japan

*Corresponding author: T Yamashita, Department of Molecular Neuroscience, Graduate School of Medicine, Osaka University, 2-2 Yamadaoka, Suita, Osaka 565-0871, Japan. Tel: +81 66879 3661; Fax: +81 66879 3669; E-mail: yamashita@molneu.med.osaka-u.ac.jp

Keywords: Th1 cells; spinal cord injury; axonal sprouting

Abbreviations: CNS, central nervous system; SCl, spinal cord injury; IL-10, interleukin 10; Th1 cells, type 1 helper T cells; Th2 cells, type 2 helper T cells; Th17, IL-17-producing helper T cells; CD4, cluster of differentiation 4; PBS, phosphate-buffered saline; CST, corticospinal tract; BDA, biotin-dextran amine; 5-HT, 5-hydroxytryptamine; GFAP, glial fibrillary acidic protein; Arg1, Arginase 1; BDNF, brain-derived neurotrophic factor; NT-3, neurotrophin-3; GDNF, glia-derived neurotrophic factor; ELISA, enzyme-linked immunosorbent assay

Received 09.12.11; revised 13.6.12; accepted 03.7.12; Edited by A Verkhratsky
} 
after CNS injury, as we previously identified that cocultured Th1-conditioned lymphocytes promote neurite outgrowth from cortical neurons. ${ }^{19}$ Here, we report that the transfer of Th1-conditioned cells, but not Th2- or Th17-conditioned cells, facilitated recovery of sensorimotor function after $\mathrm{SCl}$.

\section{Results}

Adoptive transfer of Th1-conditioned cells improves motor performance and tactile sensation after $\mathrm{SCl}$. We assessed whether transfer of Th1-, Th2-, or Th17-conditioned lymphocytes ex vivo modulated disease progression in a mouse model of $\mathrm{SCl}$. We isolated cluster of differentiation $4^{+}\left(\mathrm{CD}^{+}\right) \mathrm{T}$ cells from mice spleens and then cultured them to induce differentiation into each subset of helper $\mathrm{T}$ cells in vitro. Intracellular cytokine staining revealed differentiation into Th1, Th2 (Figure 1a), and Th17 cells (Figure 1b). As $\mathrm{T}$ cells in C57BL/6 J mice congenitally tend to skew into Th1 cells, ${ }^{20}$ we observed comparatively enriched Th1 cells in Th1-conditioned cells (Figure 1a, left). The efficiencies we observed were similar to that reported previously. ${ }^{20-22}$

Mouse spinal cords were contused at the level between thoracic vertebrae 9 (Th.9) and Th. 10 by an impactor with a force of 60 kilodyne. All of the spinally injured mice became completely paraplegic on the first day after the injury, gradually displaying partial recovery of locomotor behavior. We carried out adoptive transfer of $5.0 \times 10^{6}$ Th1- or Th2conditioned cells, which were activated with anti-CD3 and anti-CD28 antibodies for $3 \mathrm{~h}$ before the injection, at 4 days after $\mathrm{SCl}$, and observed recovery of motor function as assessed by Basso Mouse Scale (BMS). The motor recovery

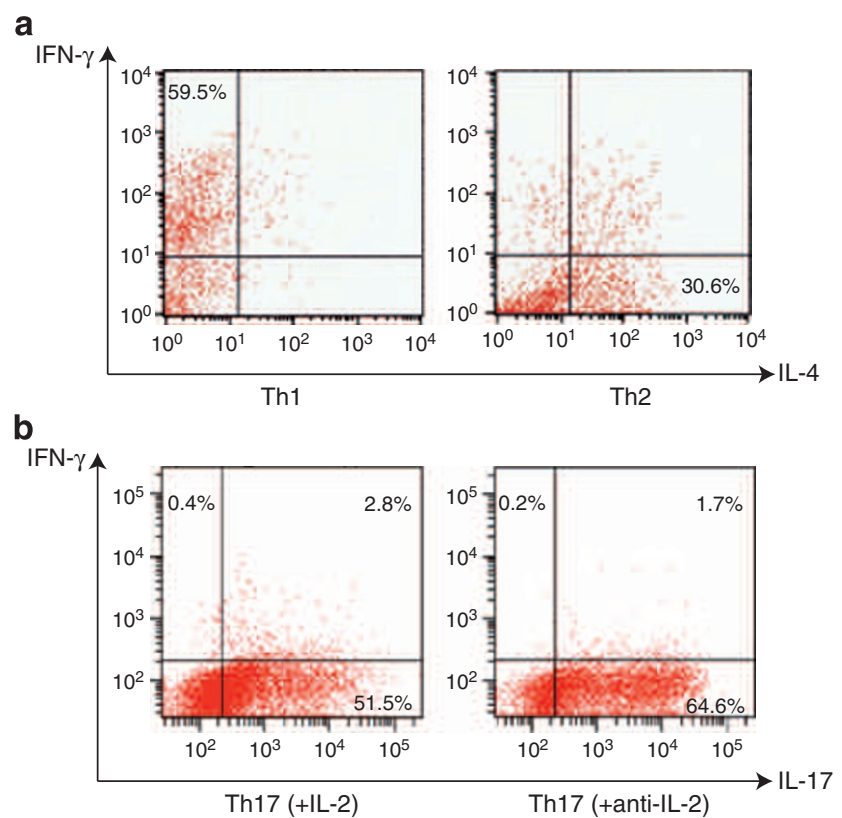

Figure 1 Intracellular staining of cytokines in cultured helper T-cell subsets. (a) Cytokine profile of Th1- and Th2-conditioned cells differentiated in vitro. (b) Cytokine profile of Th17-conditioned cells differentiated in vitro in the presence of IL-2 (left) or anti-IL-2 neutralizing antibody (right). Representative data are shown from two to three independent experiments was transiently but significantly higher from 2 to 5 weeks after $\mathrm{SCl}$ in mice in which Th1-conditioned cells, but not Th2-conditioned cells, were transferred compared with phosphate-buffered saline (PBS)-injected mice (Figure 2a). We then increased the number of transferred $T$ cells to maintain the effect of the transferred cells in the chronic phase. After the adoptive transfer of $1.0 \times 10^{7}$ Th1-conditioned cells, the mice showed significantly better motor performance after $\mathrm{SCl}$ than did PBS-injected $\mathrm{SCl}$ mice during the observation period up to 10 weeks (Figure 2b). Again, no difference was observed between mice transferred with Th2 cells and control mice (Figure 2b). Because cultured helper $\mathrm{T}$ cells are often restimulated for longer than $24 \mathrm{~h},{ }^{23}$ we addressed whether longer restimulation leads to enhanced recovery. Adoptive transfer of Th1-conditioned cells that had been restimulated with anti-CD3/anti-CD28 antibodies for $24 \mathrm{~h}$, longer than $3 \mathrm{~h}$, into mice on day 5 after $\mathrm{SCl}$ also promoted the recovery (Figure 2c). However, the recovery level was similar to that shown in Figure $2 \mathrm{~b}$. The result suggests that cultured Th1-conditioned cells that were restimulated for $3 \mathrm{~h}$ were adequately activated.

We hypothesized that Th17 cells, which have been implicated in the pathology of EAE, ${ }^{17}$ might exacerbate functional recovery after SCl. More than $50 \%$ of Th17conditioned cells that were cultured in the presence of IL-2 differentiated into Th17 cells (Figure 1b, left). The hindlimb locomotor performance of mice intraperitoneally (i.p.) injected with Th17-conditioned cells did not show improvement compared with that of control mice (Figure 2b). As IL-2 may have negative effects on Th17 differentiation, ${ }^{24}$ we added anti-IL-2 neutralizing antibody to the culture to promote Th17 differentiation (Figure 1b, right). When these Th17-conditioned cells were transferred after $\mathrm{SCl}$, motor recovery was transiently exacerbated on day 7 after $\mathrm{SCl}$ (Figure 2d).

Consistent results were obtained when we performed the inclined plane task, which is considered to correlate with rubrospinal tract integrity, after $\mathrm{SCl}$ (Figure 2e). Thus, transfer of Th1-conditioned cells effectively enhanced motor recovery after SCl.

We next assessed tactile sensation by applying von Frey monofilaments to the plantar surface of the hindpaws. We tested hindpaw withdrawal thresholds in response to a sequence of ascending mechanical stimuli of increasing force. We observed significantly better improvement of tactile sensation at day 70 after $\mathrm{SCl}$ in mice with transfer of Th1 cells compared with control mice (Figure 2f). Thus, adoptive transfer of Th1-conditioned cells enhanced amelioration of sensory function after $\mathrm{SCl}$.

Adoptive transfer of Th1-conditioned cells promotes remodeling of the injured corticospinal tract and raphespinal tract, and facilitates myelination after $\mathrm{SCl}$. We assumed that the treatment promoted restoration of the neural network for motor function. We examined axonal regrowth of the descending corticospinal tract (CST) by injecting biotin-dextran amine (BDA) into sensorimotor cortices. We observed axon arbors extending from the main CST into the gray matter rostral to the lesion site in both mice with Th1-conditioned cell transfer and control mice in the 

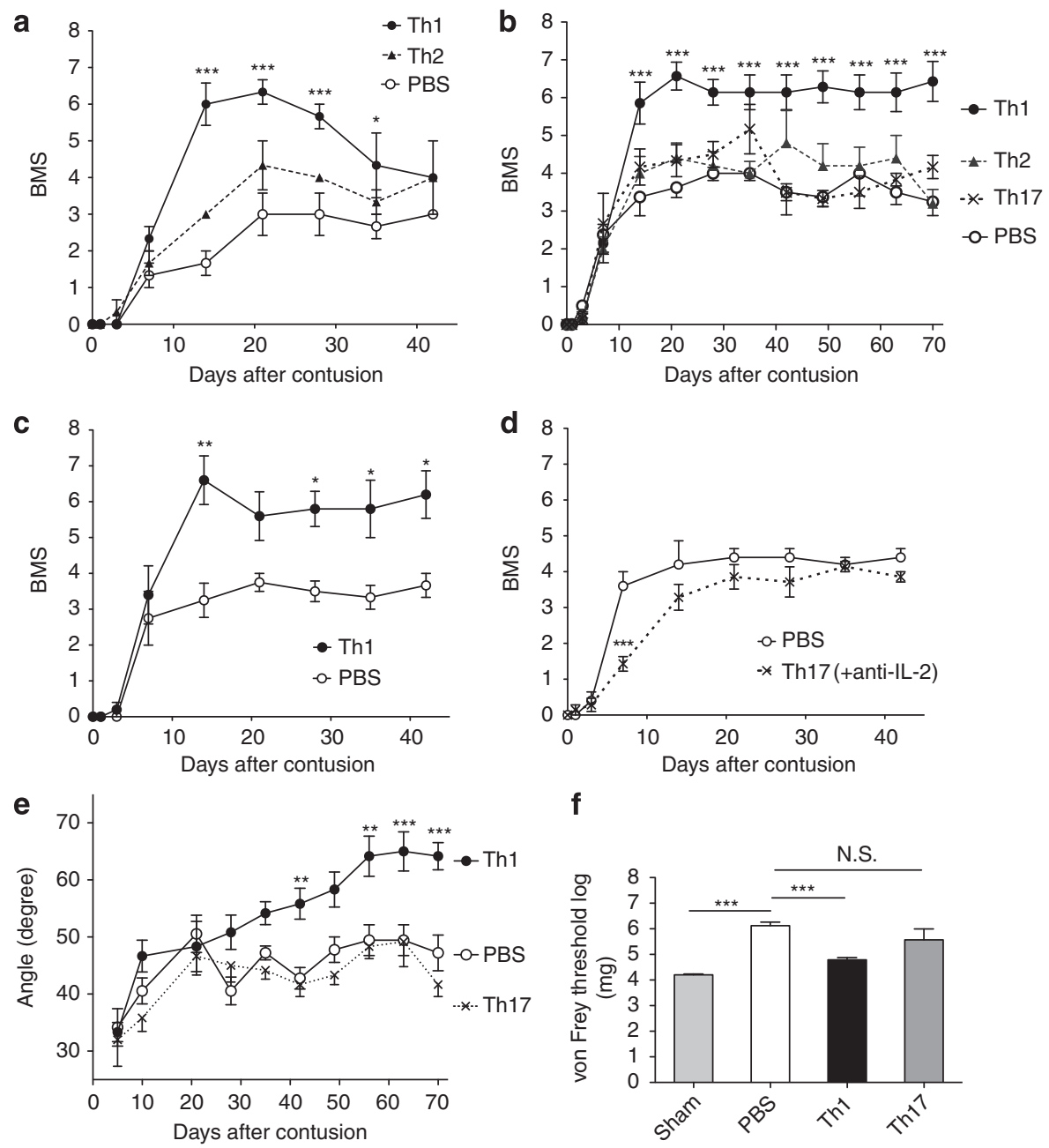

Figure 2 Transfer of Th1-conditioned cells ameliorates functional recovery after spinal cord injury (SCI). (a) BMS scores are shown for SCI mice after the transfer of $5.0 \times 10^{6}$ Th1- or Th2-conditioned cells (PBS, $n=3$; Th1, $n=3$; Th2, $n=3$ ). (b) Time course of hindlimb locomotion scored by BMS with adoptive transfer of $1.0 \times 10^{7}$ each helper T-cell subsets. Transfer of Th1-conditioned cells improved BMS score after SCI (PBS, $n=8$; Th1, $n=7 ;$ Th2, $n=5 ;$ Th17, $n=6$ ). (c) Time course of BMS scores after $\mathrm{SCl}$ followed by transfer of Th1-conditioned cells stimulated with anti-CD3/anti-CD28 antibodies for $24 \mathrm{~h}$ (PBS, $n=4 ;$; Th1, $n=5$ ). (d) Time course of BMS scores for SCI mice after the transfer of anti-IL-2 antibody-treated Th17-conditioned cells (PBS, $n=5$, Th17 + anti-IL-2, $n=7$ ). (e) Time course of the inclined plane task. Th1-conditioned cells improved the angle of the inclined plane task (PBS, $n=9$; Th1, $n=6$; Th17, $n=6$ ). (f) Tactile sensation scored using the von Frey threshold at day 70 after SCl. Th1-conditioned cells improved tactile sensation after SCl. Sham SCI, $n=4$; PBS, $n=5$; Th1, $n=4$; Th17, $n=3$. Data are mean $\pm S$.E.M. ${ }^{*} P<0.05$, ${ }^{* *} P<0.01$, ${ }^{* * \star} P<0.001$; N.S., not significant versus the PBS group (two-way ANOVA with repeated measures, Bonferroni post-test (analysis of motor function-score) or one-way ANOVA with Dunnett post-test (analysis of sensory function-score))

transverse plane (Figure 3a). CST sprouting was quantitatively evaluated by the percentage of BDA-positive area compared with $5 \mathrm{~mm}$ rostral from the injured site. We did not detect BDA-positive fibers at or more than $1 \mathrm{~mm}$ caudal to the injured site in either group of mice (Figure $3 b$ ); this finding revealed that the lesion completely transected the axons in the descending CST. On the basis of quantitative analysis of the reconstructed spinal cord, we concluded that transfer of Th1 cells significantly enhanced axon sprouting of the CST rostral to the injured site after $\mathrm{SCl}$.

As the serotonergic raphespinal tract contributes to motor function, ${ }^{25}$ we assessed regrowth of descending serotonergic raphespinal tract axons using anti-5-hydroxytryptamine (anti$5-\mathrm{HT}$ ) immunostaining at 6 weeks after SCl (Figures 3c-f). Regrowth of raphespinal tract fibers was evaluated by $5-\mathrm{HT}$ positive area compared with $5 \mathrm{~mm}$ rostral from the injured site and measuring the 5-HT-positive fibers at $1 \mathrm{~mm}$ intervals rostral or caudal to the lesion epicenter. More 5-HT-positive fibers were observed in the spinal cord caudal to the injured site in Th1-treated mice than in PBS-injected mice, demonstrating that transfer of Th1-conditioned cells enhanced the growth of serotonergic nerve fibers after $\mathrm{SCl}$ (Figures $3 \mathrm{c}$ and d). We observed no difference in the 5-HT-positive area at $5 \mathrm{~mm}$ rostral to the injured site between the 2 groups (Figures $3 e$ and $f$ ). These results support our notion that transfer of Th1-conditioned cells promotes remodeling of injured axons, thus leading to enhanced locomotor recovery after SCl.

To evaluate lesion size and tissue sparing, we carried out immunohistochemistry for glial fibrillary acidic protein (GFAP) at 6 weeks after $\mathrm{SCl}$, and assessed the lesion area that was delineated by reactive astrocytes that were 


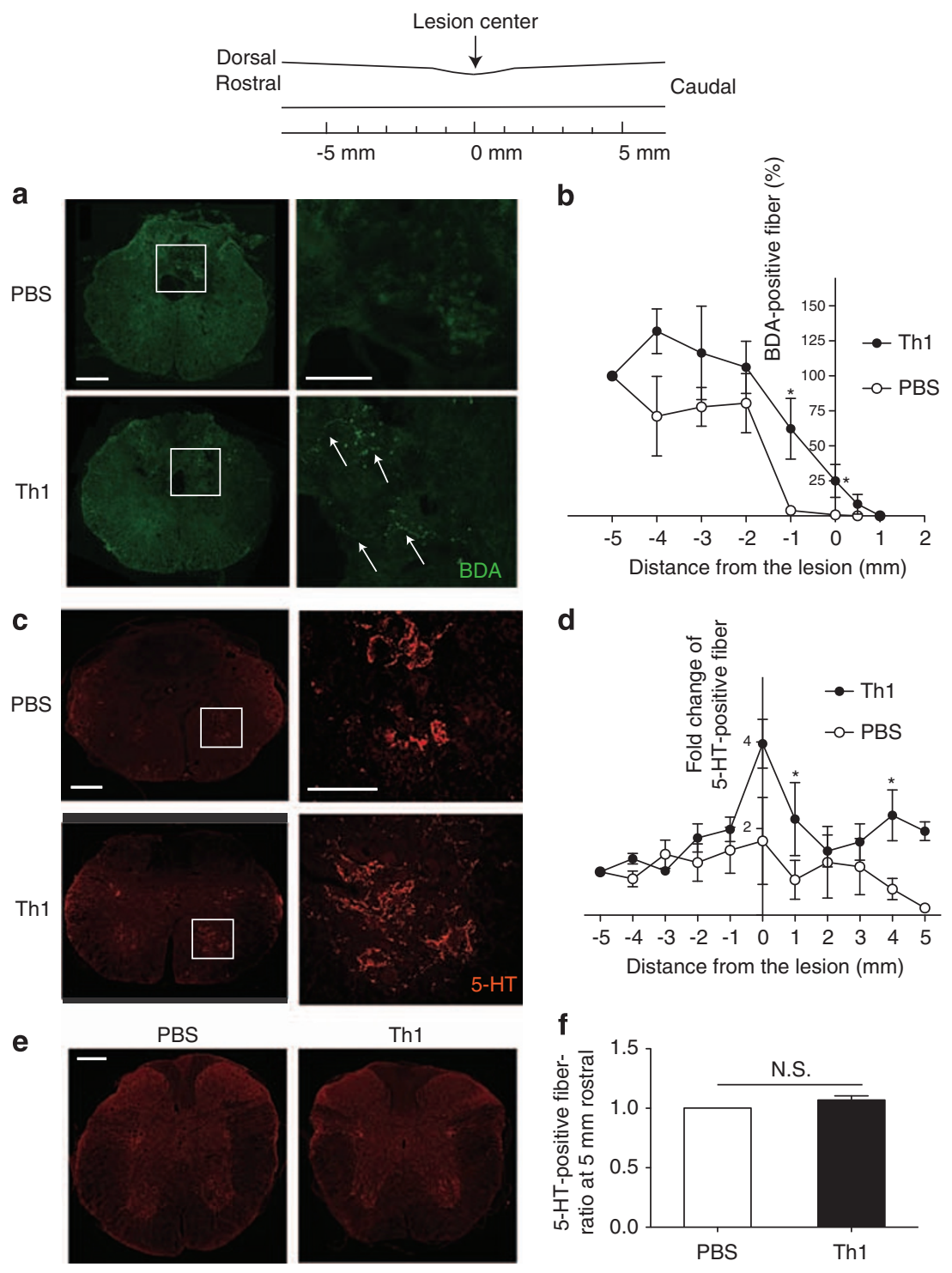

Figure 3 Transfer of Th1-conditioned cells promotes sprouting of the CST and raphespinal tract, and myelination after sSCI. The injured spinal cord is schematically illustrated (upper panel). (a) Representative images of BDA-labeled CST fibers (green) in transverse sections of the lesion epicenter; the pictures on the right are higher magnification views of the boxed regions of the pictures on the left. Arrows indicate sprouting fibers of a contused spinal cord into which the Th1-conditioned cells were transferred. Scale bar: left, $200 \mu \mathrm{m}$; right, $100 \mu \mathrm{m}$. (b) Quantification of the extent of CST growth/sprouting. The $x$-axis represents specific locations along the rostrocaudal axis of the spinal cord; the $y$-axis indicates the ratio of the average pixel number of axons at each rostrocaudal location outside the main CST to the pixel number of labeled fibers in the region $5 \mathrm{~mm}$ rostral to the lesion epicenter. Transfer of Th1-conditioned cells increased the sprouting of CST after SCI. PBS, control $(n=4)$; Th1, transfer of Th1 ( $n=6)$. (c) Representative images of 5-HT-labeled fibers (red) in transverse sections $1 \mathrm{~mm}$ caudal to the lesion site; pictures on the right are higher magnification views of the boxed regions of the pictures on the left. Scale bar: left, $200 \mu \mathrm{m}$; right, $100 \mu \mathrm{m}$. (d) Quantification of 5-HT-positive fibers compared with those $5 \mathrm{~mm}$ rostral from the lesion site. Transfer of Th1-conditioned cells promoted raphespinal tract growth after SCI. PBS, control $(n=5)$; Th1, transfer of Th1 $(n=7)$. Scale bar: $200 \mu \mathrm{m}$. (e) Representative images of 5-HT-labeled fibers $5 \mathrm{~mm}$ rostral to the lesion site. (f) Quantification of the ratio of the 5-HT-positive area $5 \mathrm{~mm}$ rostral to the lesion site in Th1-transferred mice to that in PBS-treated mice ( $n=4$ pairs of PBS/Th1). N.S., not significant (Paired $t$ test). ${ }^{*} P<0.05$ versus the control group (Mann-Whitney $U$ test)

positive for GFAP. We observed no difference in the lesion shape, the lesion size, or the size of the spared tissues between PBS-injected mice and Th1 cell-transferred mice (Figures $4 a-c)$.

Spared myelination is a hallmark of protective effects on injured neural networks. We performed myelin staining of spinal cord transverse sections at 6 weeks after $\mathrm{SCl}$ using FluoroMyelin (Figures $4 \mathrm{~d}$ and e). We assessed the percentage of FluoroMyelin-positive myelinated area relative to the total area of white matter measured at $3 \mathrm{~mm}$ rostral to the lesion site. In both PBS-injected and Th1-transfer groups, the highest degree of demyelination occurred at the epicenter (Figure 4e). However, quantification of the data demonstrated that myelinated area was increased around the epicenter in mice undergoing Th1-conditioned cell transfer compared with control mice (Figures $4 \mathrm{~d}$ and e). These results suggest that the Th1-conditioned cell transfer attenuated secondary damage and protected myelin after $\mathrm{SCl}$. 
a

PBS

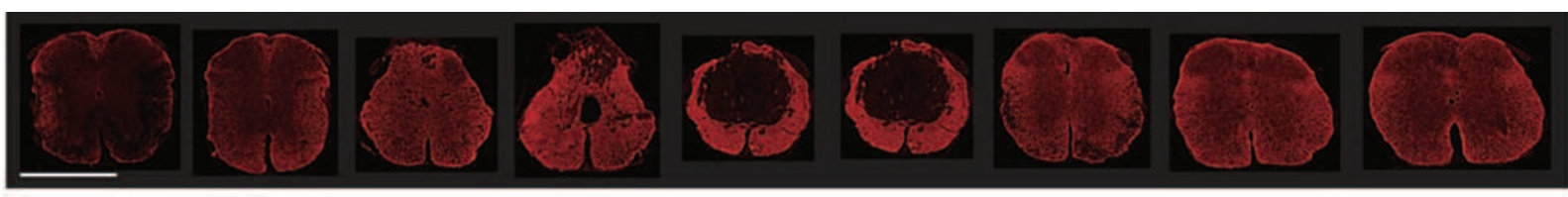

$-3 \mathrm{~mm}$

$-2 \mathrm{~mm}$

$-1 \mathrm{~mm}$

$-0.5 \mathrm{~mm}$

$0 \mathrm{~mm}$

$0.5 \mathrm{~mm}$

$1 \mathrm{~mm}$

$2 \mathrm{~mm}$

$3 \mathrm{~mm}$

Th1

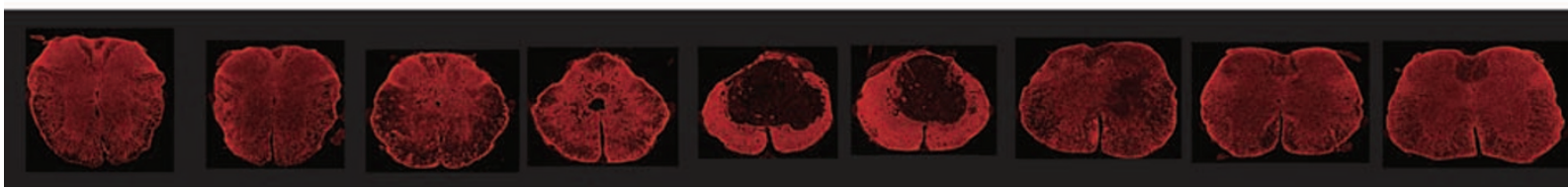

b

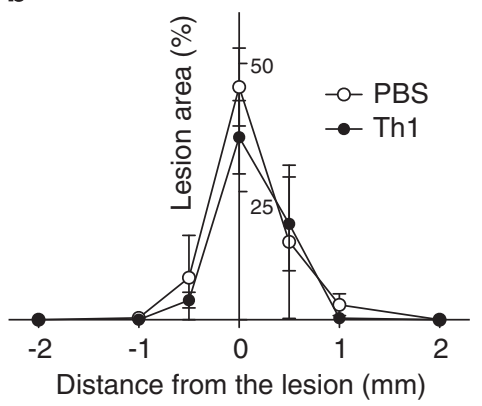

C Spared tissue (\%)

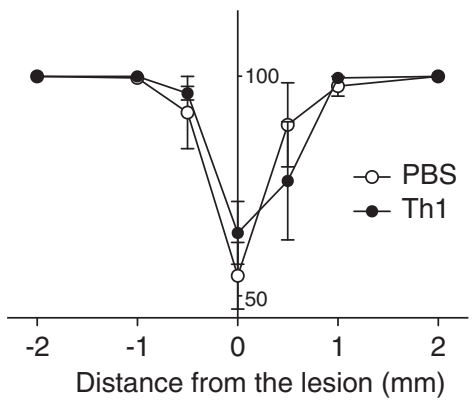

d

PBS

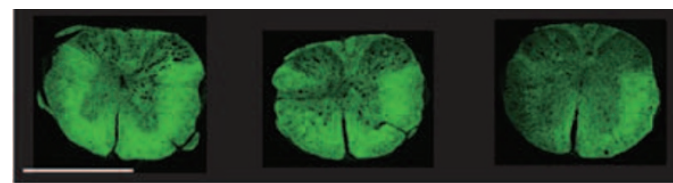

$-3 \mathrm{~mm}$

$-2 \mathrm{~mm}$

$-1 \mathrm{~mm}$

$0 \mathrm{~mm}$

$1 \mathrm{~mm}$

$2 \mathrm{~mm}$

$3 \mathrm{~mm}$
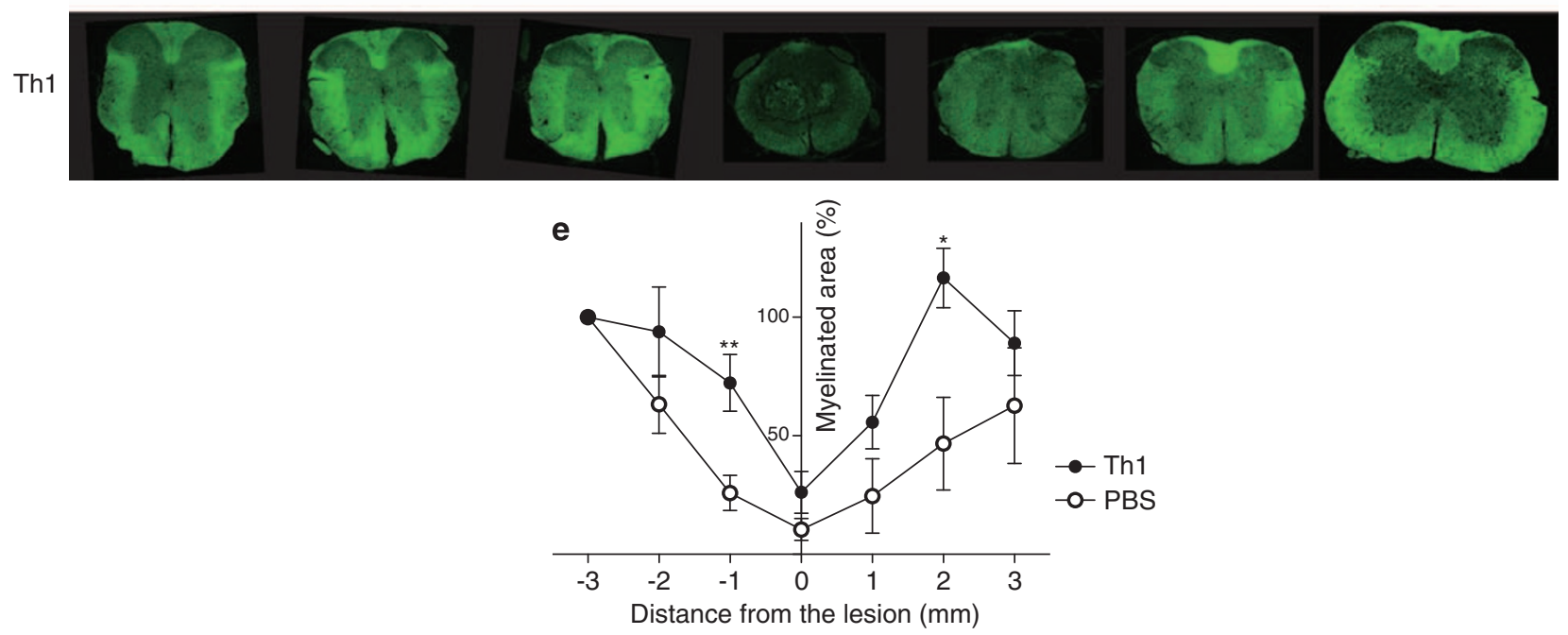

Figure 4 (a) Representative cross-sections of the spinal cords at the indicated distance from the lesion epicenter. These sections were immunostained for GFAP. Scale bar: $500 \mu \mathrm{m}$. (b) Quantification of the lesion area surrounded by reactive astrocytes in the cross-sections at the indicated distance from the lesion epicenter. PBS, control $(n=4)$; Th1, transfer of Th1 $(n=4)$. (c) Quantification of the spared tissue in the spinal cord. PBS, control $(n=4)$; Th1, transfer of Th1 $(n=4)$. No significant differences were observed (b and c, Mann-Whitney $U$ test). (d) Staining of spared myelin sheath using FluoroMyelin. Scale bar: $500 \mu \mathrm{m}$. (e) Quantification of the FluoroMyelin-positive area compared with that $3 \mathrm{~mm}$ rostral from the lesion epicenter. Transfer of Th1-conditioned cells improved myelination after SCI. PBS, control $(n=6)$; Th1, transfer of Th1 $(n=7)$. ${ }^{*} P<0.05,{ }^{* *} P<0.01$ versus the control group (Mann-Whitney $U$ test)

Adoptive transfer of Th1-conditioned cells upregulates M2 subtype of microglia and macrophages after SCl. To elucidate the mechanistic basis of the effects induced by Th1-conditioned cell transfer, we analyzed immune cell accumulation in the injured spinal cord. We observed that more than $3.0 \times 10^{6}$ leukocytes infiltrated the injured spinal cord at day 4 after SCI (Figure 5a). Because beneficial role of microglia and macrophages in the CNS have been 

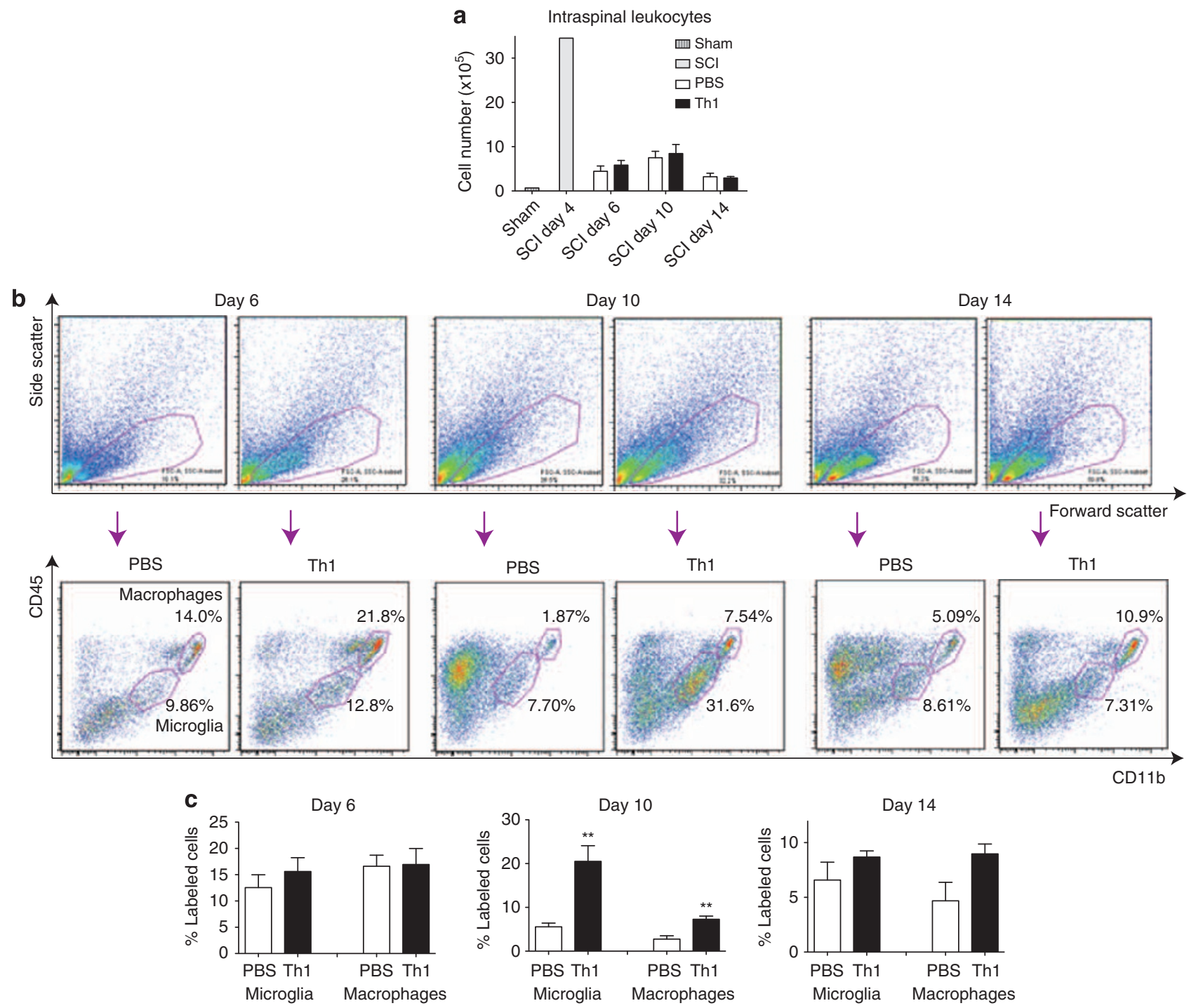

Figure 5 Increase of microglia/macrophages induced by adoptive transfer of Th1-conditioned cells after SCI. (a) Time course of leukocyte infiltration into the injured spinal cord. Th1-conditioned cells or PBS were injected i.p. on day 4 after SCl. (b) Representative profile of flow cytometric analysis of microglia/macrophages accumulated in the spinal cord on SCI days 6, 10, and 14 (2, 6, and 10 days, respectively, after PBS injection or Th1 cell transfer) of PBS or Th1-conditioned cells. Upper dot plots indicate sidescatter/forward-scatter profile by which CD11b/CD45 profiles were gated. In lower dot plots, CD11 bi intermediate $C D 45^{\text {intermediate }}$ corresponds to microglia, whereas CD11b $b^{\text {high }}$ CD45 high corresponds to macrophages. (c) Quantification of microglia/macrophages accumulated in the injured spinal cord. Leukocytes isolated from the spinal cords of 2-4 mice were analyzed in each experiment. Representative data are shown from 3-4 independent experiments. ${ }^{* *} P<0.01$ versus the control group (Student's $t$ test)

reported, ${ }^{26-28}$ we investigated the profile of microglia and macrophages after $\mathrm{SCl}$ by evaluation of $\mathrm{CD} 11 \mathrm{~b}$ and $\mathrm{CD} 45$ immunoreactivity, with a fluorescence-activated cell sorter. The dot plots revealed that microglia and macrophages increased with Th1-conditioned cell transfer on day 10 after $\mathrm{SCl}$ (Figures $5 \mathrm{~b}$ and $\mathrm{c}$ ). Microglia/macrophages can be classified into two subtypes: pro-inflammatory M1 and antiinflammatory M2. ${ }^{28,29}$ The M1 subtype is considered to express neurotoxic effects, whereas the M2 subtype is considered to exhibit neuroprotective effects after a central nervous system injury. We performed flow cytometry by employing antibodies against markers for M1 (CD86 and IL-6) and M2 (CD206 and Arginase 1 (Arg1)) subtypes. Although the number of M1 marker-positive cells was not changed after Th1 transfer (data not shown), the number of
$\mathrm{CD}^{2} 6^{+}$cells among the macrophages increased at 10 days after SCl (Figures $6 a$ and b). In addition to $\mathrm{CD}_{206}{ }^{+}$cells, the number of $A r g 1^{+}$cells among the microglia increased after Th1 transfer at 10 and 14 days after SCl (Figures $6 \mathrm{c}$ and d). These flow cytometry analyses demonstrated that Th1 cell transfer after $\mathrm{SCl}$ upregulated M2 subtype of microglia/ macrophages.

IL-10 produced by Th1-conditioned cells is necessary for the recovery after SCl. As Th1 cells are reported to express IL-10, ${ }^{30}$ which is known to be cerebroprotective ${ }^{29}$ and IL-10 expression in Th1-conditioned cells was observed (Figure $7 \mathrm{a}$, right), we addressed whether IL-10 was required for the effects of Th1-conditioned cells on recovery from SCl. Th1-conditioned cells were restimulated with 
a

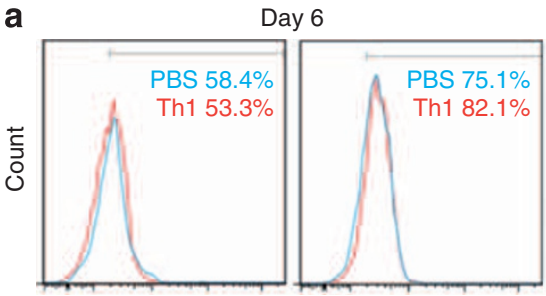

Microglia
Day 10

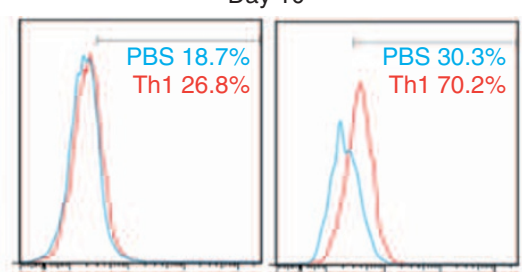

Macrophages

Microglia
Day 14

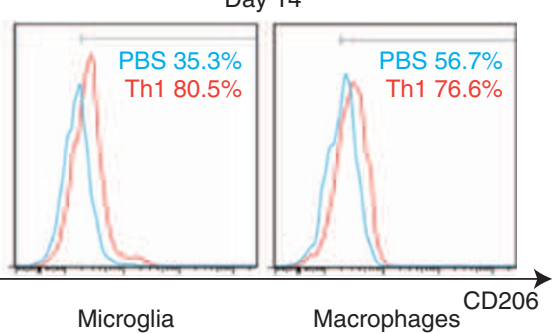

b

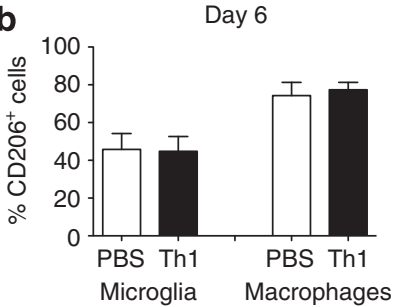

Day 10

Day 14
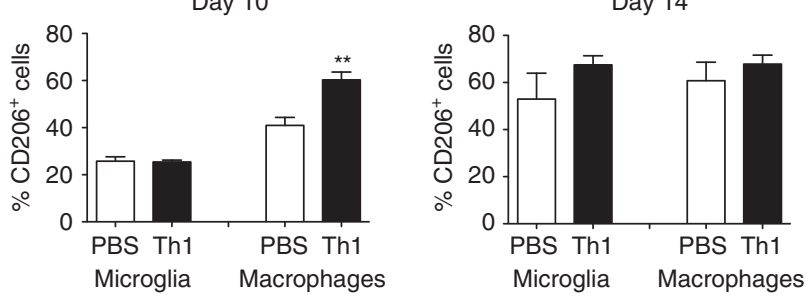

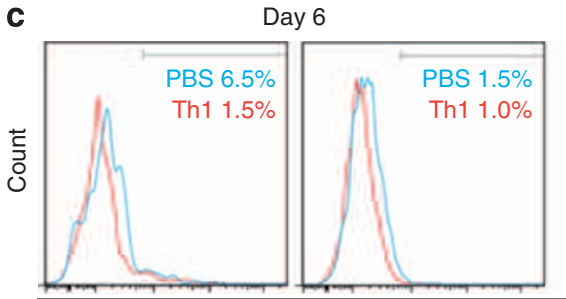

Microglia
Macrophages

Day 6

d

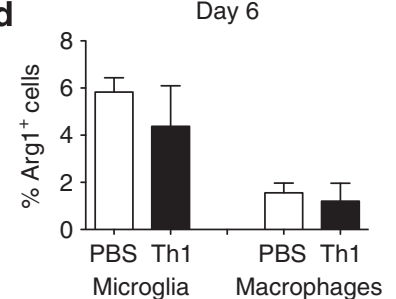

Day 10

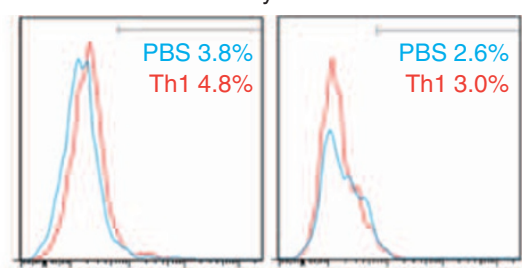

Macrophages

Day 10

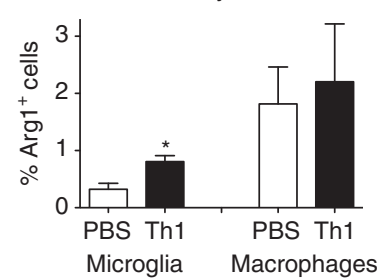

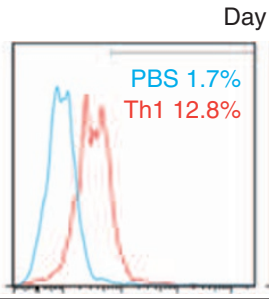

Microglia

Day 14

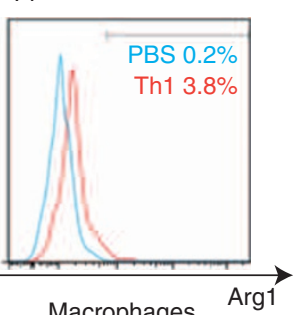

Day 14

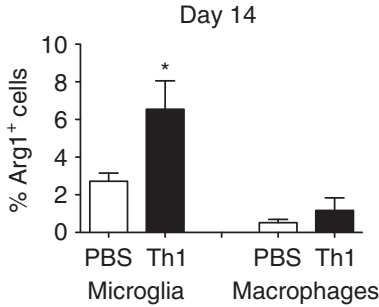

Figure 6 Transfer of Th1-conditioned cells after SCl promotes upregulation of M2 microglia/macrophages. (a) Histograms of CD206 expression on microglia and macrophages after SCl. (b) Quantification of $\mathrm{CD}_{20} 6^{+}$microglia/macrophages at the indicated days after SCl. (c) Histograms of Arg1 expression on microglia and macrophages after SCl. (d) Quantification of $\mathrm{Arg}^{+}$microglia/macrophages at the indicated days after SCl. $n=3-4$. All the data of the histograms were gated from the populations of microglia or macrophages as shown in Figure $5 b .{ }^{*} P<0.05,{ }^{* *} P<0.01$ versus control group (Student's $t$ test)

anti-CD3/anti-CD28 antibodies, simultaneously treated with anti-IL-10 neutralizing antibody, and then adoptively transferred with the antibody at day 4 after $\mathrm{SCl}$, followed by injection of anti-IL-10 antibody i.p. at days 5, 7 and 11. AntiIL-10 antibody treatment significantly attenuated the effect of Th1-conditioned lymphocytes (Figure 7b). This result demonstrates that IL-10 in Th1-conditioned lymphocytes is necessary for the promotion of functional recovery from $\mathrm{SCl}$.

Th1-conditioned lymphocytes secrete neurotrophic factors. To find candidate molecules in Th1-conditoned cells responsible for axonal sprouting after contusion $\mathrm{SCl}$, we assessed the expression of neurotrophic factors such as brainderived neurotrophic factor (BDNF), neurotrophin-3 (NT-3), and glia-derived neurotrophic factor (GDNF) with enzymelinked immunosorbent assay (ELISA) because they were reported to be expressed in activated $\mathrm{T}$ cell. ${ }^{6}$ The expression level of NT-3 was higher in Th1 cells than in Th2 or Th17 cells (Figure 8a). However, BDNF expression was under the detection level among any $T$ cell subsets (data not shown). Expression levels of GDNF in Th1- and Th2conditioned cells were higher than that of Th17-conditioned cells (Figure $8 \mathrm{~b}$ ), but the absolute amount was around $30 \mathrm{pg} / \mathrm{ml}$, which was much smaller than that of NT-3.

\section{Discussion}

The efficacy of T-lymphocyte transfer after CNS injury has been controversial, ${ }^{18,31}$ and the detailed phenomena and mechanisms underlying the intervention are poorly understood. In the present study, we addressed our hypothesis that the beneficial and harmful effects of transferred T cells could 

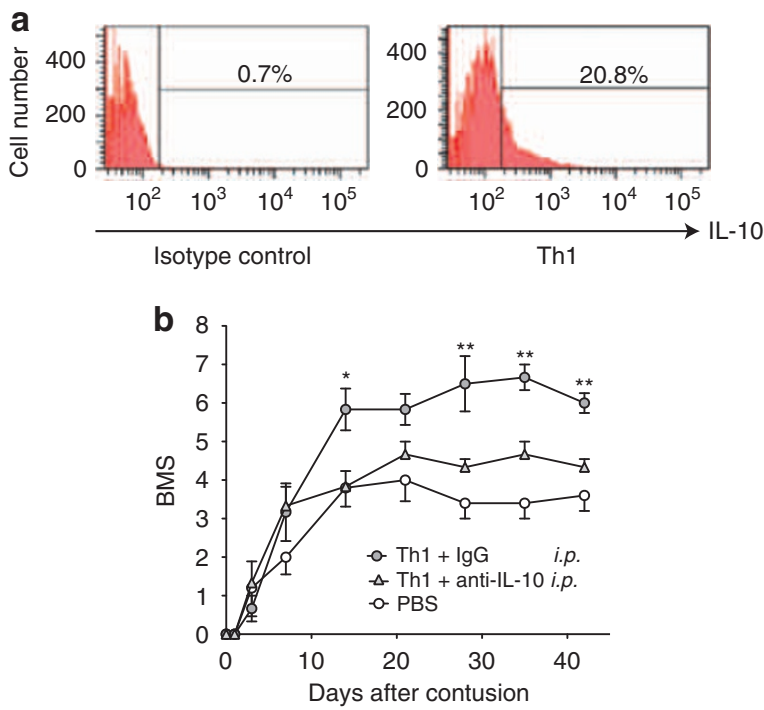

Figure 7 Expression of IL-10 in Th1-conditioned cells contributes to functional recovery after $\mathrm{SCl}$ with adoptive transfer of Th1-conditoned cells. (a) IL-10 expression in Th1 cells is shown as representative histograms from two independent experiments. (b) BMS scores in $\mathrm{SCl}$ mice with transfer of Th1conditioned cells. These Th1-conditioned cells and mice were treated with control IgG or anti-IL-10 antibody (PBS, $n=5$; Th1 $+\lg G, n=6$; and Th1 + anti-IL-10, $n=6$ ). ${ }^{*} P<0.05 ;{ }^{* *} P<0.01$ versus anti-IL-10 + Th1 group (two-way ANOVA with repeated measures, Bonferroni post-test)
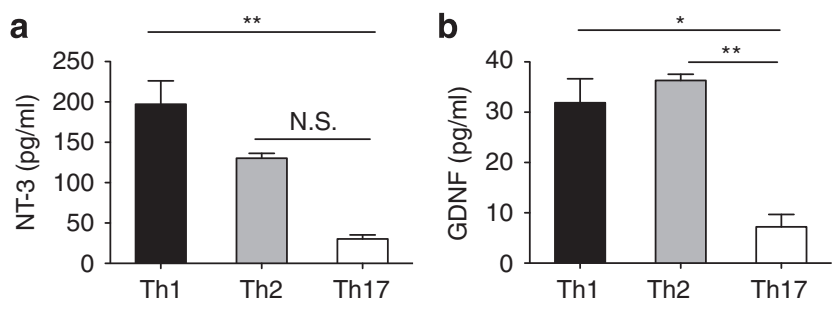

Figure 8 Expression of neurotrophic factors in subsets of T cells. NT-3 (a) and GDNF (b) in the supernatant of Th1, Th2, and Th17 cells detected by ELISA (Th1, $n=6$; Th2, $n=3$; Th17, $n=3$ ). ${ }^{*} P<0.05 ;{ }^{*} P<0.01$; N.S., not significant (one-way ANOVA with Dunnett post-test)

be explained by the distinct roles of helper T-cell subsets. Adoptive transfer of cultured Th1-conditioned cells into mice improved functional recovery after SCl. Although Th2 cells were suggested to be beneficial after CNS injury, ${ }^{18}$ this was not the case in our experimental paradigm. Recovery of hindlimb locomotion by Th1 transfer after SCl coincides with improved neuronal network associated with motor function. Activation of monocytes by Th1 cell transfer may have a role in improved CST sprouting and myelination after $\mathrm{SCl}$, as monocyte-derived cells are required for remyelination after toxin-induced demyelination ${ }^{32}$ or EAE. ${ }^{26}$

The reported detrimental effects of $T$ cells after CNS trauma ${ }^{14,15}$ may be due to the function of specific subsets of T cells, such as Th17 cells and IL-17-producing $\gamma \delta$ T cells. Indeed, we observed transfer of Th17-conditoned cells transiently exacerbated motor function (Figure 2d).

Activation of monocytes by Th1 cell transfer may have a role in enhanced CST sprouting and myelination after SCl, as monocyte-derived cells are required for remyelination after toxin-induced demyelination ${ }^{32}$ or EAE. ${ }^{26}$ It is also known that activated microglia induce neuronal differentiation ${ }^{33}$ and are neuroprotective. ${ }^{28}$ Specifically, M1 subtype of microglia/ macrophages is considered pro-inflammatory, whereas M2 subtype is considered phagocytic and tissue-protective. ${ }^{28}$ Indeed, we identified that microglia and macrophages were activated by transfer of Th1-conditoned cells and that M2 subtype of microglia/macrophages was upregulated (Figures 5 and 6). It should be noted that transfer of IFN- $\gamma$-producing Th1 cells that had been considered proinflammatory promoted upregulation of anti-inflammatory M2 subtype of microglia/macrophages after SCl.

The differentiating characteristic of our treatment from others ${ }^{7,10,15}$ is that the transferred T cells in the present study were not immunized by CNS proteins, such as myelin basic protein or myelin oligodendrocyte glycoprotein. The fact that we observed little infiltration of the transferred Th1-conditioned cells into the injured spinal cord (data not shown) suggests that these cells did not attack the CNS.

Importantly, IL-10 expressed by Th1-conditioned cells has beneficial role in promoting functional recovery (Figure 7 ). Although Th2 cells also express IL-10, ${ }^{30}$ Th2-conditioned cells did not show beneficial effects on functional recovery after SCl in our model (Figures 2a and b). Thus, expression of IL-10 from Th1-conditoned cells may contribute to maintaining the cells in an effective state in vivo rather than directly modulating the lesion sites.

Taken together, our successful intervention with cultured Th1-conditoned cells may shed light on a future immunomodulatory treatment for CNS injury.

\section{Materials and Methods}

Mice. C57BL/6 mice were purchased from Charles River Laboratories. All mice used in this study were housed in specific pathogen-free conditions, and were treated and cared for in accordance with the guidelines of the Osaka University pertaining to the treatment of experimental animals.

Animal model of SCl. Adult (7-9 weeks old) female C57BL/6 mice were anesthetized with sodium pentobarbital (50 mg/kg; Kyoritsu Seiyaku, Tokyo, Japan). Following dorsal laminectomy (Th.9-Th.10 level), the spinal cord was contused with a force of 60 kilodyne using an Infinite Horizon Impactor (Precision Systems \& Instrumentation, Fairfax Station, VA, USA) as previously described. ${ }^{34}$ The muscle and skin layers were then sutured. The bladder was expressed by manual abdominal pressure every day until 10 days post-injury. Food and water were provided ad libitum.

Adoptive transfer of cultured $\mathbf{T}$ cells. Spleens and lymph nodes (axillary and cervical) were collected from C57BL/6J female mice. The spleens were mechanically disrupted, washed twice, and resuspended in cold PBS. The lymph nodes were also mechanically disrupted and incubated on ice for $5 \mathrm{~min}$ followed by collection of the supernatant and centrifugation at 1400 r.p.m. The pellet was then suspended in cold PBS. These samples were filtrated with a 70- $\mu \mathrm{m}$ Cell Strainer (BD Biosciences, Franklin Lakes, NJ, USA) and suspended in RPMI 1640 medium (Invitrogen, Carlsbad, CA, USA) supplemented with 10\% fetal bovine serum (FBS), $100 \mathrm{IU} / \mathrm{ml}$ penicillin, $100 \mu \mathrm{g} / \mathrm{ml}$ streptomycin, $1 \mu \mathrm{M}$ sodium pyruvate, and $2.5 \mu \mathrm{M} \beta$-mercaptoethanol (RPMl growth medium). $\mathrm{CD}^{+}{ }^{+} \mathrm{T}$ cells were isolated by magnet sorting with anti-CD4 magnet beads according to the manufacturer's instructions (Miltenyi Biotec $\mathrm{GmbH}$, Bergisch Gladbach, Germany). $\mathrm{CD}^{+}{ }^{+} \mathrm{T}$ cells were stimulated with anti-CD3\&/anti-CD28 antibodies (BD Biosciences) coated on 24-well plates (Greiner Bio One, Kremsmünster, Austria) at a concentration of $5 \mu \mathrm{g} / \mathrm{ml}$ each. Th1-conditioned cells were differentiated by the addition of recombinant IL-2 (25 U/ml; R\&D systems, Minneapolis, MN, USA), IL-12 $(10 \mathrm{U} / \mathrm{ml} ; \mathrm{R} \& \mathrm{D}$ systems), and anti-IL-4 antibodies (25\% culture supernatant of hybridoma; clone HB-188; American Type Culture Collection, Manassas, VA, USA). 
Th2 polarization was initiated by the addition of recombinant IL-2 $(25 \mathrm{U} / \mathrm{ml}$; R\&D systems), IL-4 (100 U/ml; Peprotech, Rocky Hill, NJ, USA), and anti-IFN- $\gamma$ antibodies (1\% culture supernatant of hybridoma; clone HB-170; American Type Culture Collection). Th17-conditioned cells were differentiated by the addition of recombinant IL-6 $(20 \mathrm{ng} / \mathrm{ml}$; R\&D systems), IL-23 $(20 \mathrm{ng} / \mathrm{ml}$; R\&D systems), TGF- $\beta 1$ ( $3 \mathrm{ng} / \mathrm{ml}$; R\&D systems), anti-IL-4 antibodies ( $25 \%$ culture supernatant of hybridoma; clone HB-188; American Type Culture Collection), and anti-IFN- $\gamma$ antibodies ( $1 \%$ culture supernatant of hybridoma; clone CRL-1975; American Type Culture Collection) in the presence of recombinant IL-2 (25 U/ml; R\&D systems) or anti-IL-2 antibody ( $10 \mu \mathrm{g} / \mathrm{ml}$; R\&D systems). These CD4 ${ }^{+} \mathrm{T}$ cells were diluted $1: 3$ for passage on day 2, and cultured with IL-2 and IL-12 for Th1; IL-2 and IL-4 for Th2; and IL-6, IL-23, TGF- $\beta 1$ with or without IL-2 for Th17 in the same concentrations as above. On day 4, these helper $\mathrm{T}$ cells were harvested and overlaid on Lympholyte M (Cedarlane Laboratories, Burlington, ON, Canada) and centrifuged at $1000 \times g$ for $20 \mathrm{~min}$. The intermediate layer was collected, washed with PBS, and resuspended in RPMI growth medium. The cells were restimulated for $3 \mathrm{~h}$ with anti-CD3e and anti-CD28 antibodies (BD Biosciences) coated on 24-well plates. After restimulation with anti-CD3 $\varepsilon$ and anti-CD28 antibodies, cells were harvested and washed twice with PBS. Helper T cells $\left(5.0 \times 10^{6}\right.$ or $1.0 \times 10^{7}$ ) suspended in $500 \mu$ l PBS were injected i.p. into mice at day 4 after SCl. As a control, $500 \mu \mathrm{l}$ PBS was injected into mice after SCI. For IL-10 neutralization, Th1 cells were incubated with anti-IL-10 antibody (eBioscience; clone: JES5-16E3) or rat IgG (eBioscience, San Diego, CA, USA) at the concentration of $10 \mu \mathrm{g} / \mathrm{ml}$, and were simultaneously restimulatd with anti-CD3 $\varepsilon$ and anti-CD28 antibodies. After transfer of Th1 cells, $100 \mu \mathrm{g}$ of anti-IL-10 antibody or rat lgG (eBioscience) was injected i.p. into mice on $\mathrm{SCl}$ days 5, 7, and 11 .

Behavioral analysis. Hindlimb motor function was evaluated using the BMS open field locomotor test, in which scores range from 0 to $9 .{ }^{35}$ BMS scores were recorded at days $1,3,7,10$, and 14 post-injury, and once weekly thereafter for a total of 11 weeks. A subset of animals was analyzed using the inclined plane task, ${ }^{36}$ which evaluates the animal's ability to maintain body position on a board raised incrementally to increasing angles. Performance on the inclined plane correlates with the integrity of the rubrospinal tract (and other nonpyramidal pathways) after $\mathrm{SCl}^{37,38}$ Animals were tested at days $1,3,7,10$, and 14 postinjury, and once weekly thereafter for a total of 12 weeks. Mice were tested in each position, after which the angle was increased incrementally by $5^{\circ}$. The maximum angle at which the animal could maintain a stationary position on the board for $10 \mathrm{~s}$ was recorded.

Analysis of tactile sensation. To measure the threshold of hindpaw withdrawal to mechanical stimuli, we followed a reported procedure. ${ }^{39}$ Mice were placed within an inverted glass beaker $(10 \mathrm{~cm}$ diameter) positioned on the framework used in the grid walk test. The framework consisted of grids (1- $\mathrm{cm}^{2}$ grids) that allowed von Frey monofilaments (SAKAI Medical Co., Ltd, Tokyo, Japan) to be applied to the plantar surface of the hindpaws. We evaluated thresholds of hindpaw withdrawal using a sequence of mechanical stimuli of increasing force. Mechanical testing was performed using 20 calibrated von Frey monofilaments that delivered approximately logarithmic incremental forces of $1.65-6.65 \mathrm{mg}$. For each group, every monofilament was applied to the hindpaw for $\sim 1 \mathrm{~s}$ with at least a 10-s interval between stimulus presentations. The lowest force von Frey monofilament was applied to the right, then to the left hindpaw plantar surface, and then the next higher force von Frey was administered in the same manner. A positive withdrawal response was recorded when the animal produced more than two stimulus-related withdrawals of the tested paw in three trials.

Anterograde labeling of the CST. More than 10 weeks after injury, descending CST fibers were labeled with BDA ( $10 \%$ in saline, $3.2 \mu \mathrm{l}$ per cortex, MW 10000; Invitrogen) injected under anesthesia into the left motor cortex (coordinates: $0.5-1.0 \mathrm{~mm}$ posterior to bregma, $0.5-1.0 \mathrm{~mm}$ lateral to bregma, $0.5 \mathrm{~mm}$ depth). For each injection, $0.2 \mu \mathrm{lBDA}$ was delivered over a period of $30 \mathrm{~s}$ via a $15-20-\mu \mathrm{m}$ inner diameter glass capillary attached to a microliter syringe (ITO). In total, we examined and compared the sprouting responses of four control and six Th1 cell-transferred mice after SCl. At 14 days after BDA injection, the animals were perfused with $4 \%$ paraformaldehyde (Wako Pure Chemical Industries, Osaka, Japan). The spinal cord was removed from the vertebral column and stored in $15 \%$ sucrose in $0.2 \mathrm{M}$ phosphate buffer (PB) at $4{ }^{\circ} \mathrm{C}$ for $12 \mathrm{~h}$. The spinal cord was then placed in $30 \%$ sucrose in $0.2 \mathrm{M}$ PB for $24 \mathrm{~h}$ at $4{ }^{\circ} \mathrm{C}$.
The spinal cord was embedded in Tissue Tek OCT (Sakura Finetechnical Co. Ltd, Tokyo, Japan) and immediately frozen on dry ice at $-80^{\circ} \mathrm{C}$. A series of $20-\mu \mathrm{m}$ transverse sections were cut on a cryostat and mounted on Matsunami Adhesive Silan (MAS)-coated glass slides (Matsunami Glass, Osaka, Japan). The sections were incubated in PBS with $0.3 \%$ Triton X-100 at room temperature for $5 \mathrm{~h}$, washed three times, then incubated for $2 \mathrm{~h}$ with Alexa Fluor 488-conjugated streptavidin (1: 400; Invitrogen) in PBS with $0.1 \%$ Triton X-100. The sections were viewed under an inverted light microscope equipped with epifluorescence optics and a dry condenser for phase-contrast microscopy (DP70, Olympus, Tokyo, Japan). The area of positive fluorescence in the histological section was determined by using Image J software (National Institutes of Health (NIH), Bethesda, MD, USA).

Tissue preparation and histochemistry. For histochemistry, the animals were perfused with $4 \%$ paraformaldehyde, and preserved spinal cord tissues were collected. The whole spine was dissected out and post-fixed in $4 \%$ paraformaldehyde for $3 \mathrm{~h}$ at $4{ }^{\circ} \mathrm{C}$. The spinal cord was removed from the vertebral column and stored for $12 \mathrm{~h}$ in $15 \%$ sucrose in $0.2 \mathrm{M} \mathrm{PB}$ at $4{ }^{\circ} \mathrm{C}$. The spinal cord was then placed in $30 \%$ sucrose in $0.2 \mathrm{M} \mathrm{PB}$ for $24 \mathrm{~h}$ at $4{ }^{\circ} \mathrm{C}$. The spinal cord was embedded in Tissue Tek OCT and immediately frozen on dry ice at $-80^{\circ} \mathrm{C}$. A series of 20- $\mu \mathrm{m}$ transverse sections were cut on a cryostat and mounted on MAS-coated glass slides. After washing three times with PBS, all sections were blocked in PBS containing 5\% BSA and $0.3 \%$ Triton X-100 for $1 \mathrm{~h}$ at room temperature. The sections were then incubated with primary antibodies overnight at $4{ }^{\circ} \mathrm{C}$, washed three times with PBS, and incubated with fluorescein-conjugated secondary antibodies (1:500; Invitrogen) for $1 \mathrm{~h}$ at room temperature. Sections were then rinsed three times in PBS and mounted. For primary antibodies, we used monoclonal anti-serotonin (1:2000; ImmunoStar, Hudson, WI, USA) and polyclonal anti-GFAP (1:400; Dako, Glostrup, Denmark).

Myelin staining of spinal cord cross-sections was performed using FluoroMyelin (Invitrogen) to measure the area of myelinated nerve fibers in the white matter. The area of positive fluorescence in histological sections was determined by using Image $\mathrm{J}$ software $(\mathrm{NIH})$. The ratios of the 5 -HT-positive area $5 \mathrm{~mm}$ rostral to the lesion site in the Th1-transferred SCI mice to that in the PBS-treated SCI mice were calculated using pairs of the sections (PBS-treated and Th1 cell-transferred) stained on the same day to avoid decrease of the signal intensity over time.

The sections were viewed under an inverted light microscope equipped with epifluorescence optics and a dry condenser for phase-contrast microscopy (DP70, Olympus). For $5-\mathrm{HT}$ immunohistochemistry of higher magnification views, samples were examined under a confocal laser-scanning microscope (FV1000, Olympus).

Preparation of leukocytes from injured spinal cords. We performed the extraction of leukocytes from the spinal cord according to a previously described procedure. ${ }^{40}$ Firstly, mice were transcardially perfused with ice-cold PBS. The spinal cord was then dissected and suspended in Hank's Balanced Salt Solution (Invitrogen) supplemented with $3 \% \mathrm{FBS}, 100 \mathrm{IU} / \mathrm{ml}$ penicillin, and $100 \mu \mathrm{g} / \mathrm{ml}$ streptomycin. The spinal cords were digested with collagenase D $(5.0 \mathrm{mg} / \mathrm{ml}$; Roche, Basel, Switzerland) plus $2.5 \mathrm{mM}$ calcium chloride. After filtration with a $70-\mu \mathrm{m}$ Cell Strainer (BD Biosciences), the pellet isolated by $38 \%$ Percoll centrifugation at $1500 \times g$ for 20 min was collected for flow cytometry.

Staining of cell-surface and intracellular antigens. Cultured lymphocytes were stimulated with $50 \mathrm{ng} / \mathrm{ml}$ phorbol 12-myristate 13-acetate (PMA, EMD Millipore, Billerica, MA, USA) and $750 \mathrm{ng} / \mathrm{ml}$ ionomycin (EMD Millipore) for $4 \mathrm{~h}$ and with $10 \mu \mathrm{g} / \mathrm{ml}$ brefeldin A (Sigma-Aldrich, St. Louis, MO, USA) for the last $2 \mathrm{~h}$. Collected leukocytes from mice spinal cords were incubated with $10 \mu \mathrm{g} / \mathrm{ml}$ brefeldin $\mathrm{A}$ (Sigma-Aldrich) for $2 \mathrm{~h}$. The cells were suspended in Fixation Buffer (eBioscience), preincubated with $\mathrm{Fc}$ receptor block antibody (eBioscience) for $20 \mathrm{~m}$, and surface stained with anti-CD4-PE (BD Biosciences), anti-CD45-Alexa647 (BioLegend, San Diego, CA, USA), anti-CD45-PE/Cy7 (BioLegend), anti-CD11b-PE, anti-CD11bAPC, anti-mouse CD86-APC, anti-mouse CD206-FITC (BioLegend). Intracellular staining was performed according to the manufacturer's protocol using anti-IL-10-PE (BioLegend) and anti-IL-6-FITC (eBioscience) antibodies with permiabilization buffer and staining buffer (eBioscience). For Arg1 staining, the permiabilized cells were incubated with mouse anti-Arg1 antibody (1:200; BD Biosciences) for $1 \mathrm{~h}$, washed twice, and incubated with PE-conjugated anti-mouse IgG antibody (BioLegend).

Flow cytometric analysis. Flow cytometry was performed with the FACSCalibur and FACSCanto II flow cytometers (BD Biosciences) and analyzed using ProQuest and FACSDiva (BD Biosciences), and FlowJo software 
(version 9.3.1; TreeStar, Inc., Ashland, OR, USA). Specificity of the signals of antibodies against specific antigens was determined by performing control experiments using isotype-matched immunoglobulins (BioLegend).

Enzyme-linked immunosorbent assay. Th1, Th2, and Th17 (cultured with anti-IL-2 antibody) cells were prepared as described above. Three hours after

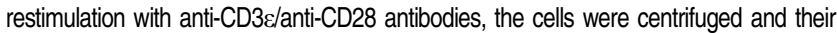
supernatants were collected and stored at $-80^{\circ} \mathrm{C}$ until use. Concentrations of NT-3, GDNF, BDNF in the supernatants of each cell were analyzed using the ELISA kits according to the manufacturer's protocol (Emax Immunoassay System (Promega, Fitchburg, WI, USA) for NT-3, GDNF, and BDNF. Absorbance values were read at $450 \mathrm{~nm}$ on a plate reader (SpectraMax M2; Molecular Devices, Sunnyvale, CA, USA).

Statistical analysis. All values are expressed as mean \pm S.E.M. We analyzed motor function scores using two-way ANOVA with repeated measures, Bonferroni posttest for 2-4 groups. Quantified histological data were analyzed by the Mann-Whitney $U$ test. However, for Figure $3 f$, the result was analyzed by paired Student's $t$ test. Student's $t$ test was used to analyze the quantified data with flow cytometry. For all other data, we used one-way ANOVA with Dunnett post-test collection for comparison of 3-4 groups. Values of $P<0.05$ were considered statistically significant.

\section{Conflict of Interest}

The authors declare no conflict of interest.

Acknowledgements. We thank Drs. T Nakayama, M Yamashita and M Kuwahara at Chiba University, and Drs. M Murakami, D Kamimura and H Okuyama at Osaka University, for their technical advice on T-cell culture; Drs. K Morimoto and S Lee at Osaka University for their help in histological assessment.

1. Taoka Y, Okajima K, Uchiba M, Murakami K, Kushimoto S, Johno M et al. Role of neutrophils in spinal cord injury in the rat. Neuroscience 1997; 79: 1177-1182.

2. Profyris C, Cheema SS, Zang D, Azari MF, Boyle K, Petratos S. Degenerative and regenerative mechanisms governing spinal cord injury. Neurobiol Dis 2004; 15: 415-436.

3. Potas JR, Zheng Y, Moussa C, Venn M, Gorrie CA, Deng C et al. Augmented locomotor recovery after spinal cord injury in the athymic nude rat. J Neurotrauma 2006; 23: 660-673.

4. Park E, Velumian AA, Fehlings MG. The role of excitotoxicity in secondary mechanisms of spinal cord injury: a review with an emphasis on the implications for white matter degeneration. J Neurotrauma 2004; 21: 754-774.

5. Moalem G, Leibowitz-Amit R, Yoles E, Mor F, Cohen IR, Schwartz M. Autoimmune T cells protect neurons from secondary degeneration after central nervous system axotomy. Nat Med 1999; 5: 49-55.

6. Hammarberg H, Lidman O, Lundberg C, Eltayeb SY, Gielen AW, Muhallab S et al. Neuroprotection by encephalomyelitis: rescue of mechanically injured neurons and neurotrophin production by CNS-infiltrating T and natural killer cells. J Neurosci 2000; 20: 5283-5291.

7. Hauben E, Butovsky O, Nevo U, Yoles E, Moalem G, Agranov E et al. Passive or active immunization with myelin basic protein promotes recovery from spinal cord contusion. J Neurosci 2000; 20: 6421-6430.

8. Yoles E, Hauben E, Palgi O, Agranov E, Gothilf A, Cohen A et al. Protective autoimmunity is a physiological response to CNS trauma. J Neurosci 2001; 21: 3740-3748.

9. Hofstetter HH, Sewell DL, Liu F, Sandor M, Forsthuber T, Lehmann PV et al. Autoreactive $T$ cells promote post-traumatic healing in the central nervous system. $J$ Neuroimmunol 2003; 134: 25-34.

10. Ziv Y, Ron N, Butovsky O, Landa G, Sudai E, Greenberg N et al. Immune cells contribute to the maintenance of neurogenesis and spatial learning abilities in adulthood. Nat Neurosci 2006; 9: 268-275.

11. Beers DR, Henkel JS, Zhao W, Wang J, Appel SH. CD4 + T cells support glial neuroprotection, slow disease progression, and modify glial morphology in an animal model of inherited ALS. Proc Natl Acad Sci USA 2008; 105: 15558-15563.

12. Chiu IM, Chen A, Zheng Y, Kosaras B, Tsiftsoglou SA, Vartanian TK et al. T lymphocytes potentiate endogenous neuroprotective inflammation in a mouse model of ALS. Proc Natl Acad Sci USA 2008; 105: 17913-17918.

13. Gimsa U, Peter SV, Lehmann K, Bechmann I, Nitsch R. Axonal damage induced by invading $T$ cells in organotypic central nervous system tissue in vitro: involvement of microglial cells. Brain Pathol 2000; 10: 365-377.

14. Fee D, Crumbaugh A, Jacques T, Herdrich B, Sewell D, Auerbach D et al. Activated/ effector CD4 + T cells exacerbate acute damage in the central nervous system following traumatic injury. J Neuroimmunol 2003; 136: 54-66.

15. Jones TB, Ankeny DP, Guan Z, McGaughy V, Fisher LC, Basso DM et al. Passive or active immunization with myelin basic protein impairs neurological function and exacerbates neuropathology after spinal cord injury in rats. J Neurosci 2004; 24: 3752-3761.
16. Shichita $T$, Sugiyama $Y$, Ooboshi $H$, Sugimori $H$, Nakagawa R, Takada I et al. Pivotal role of cerebral interleukin-17-producing gammadeltaT cells in the delayed phase of ischemic brain injury. Nat Med 2009; 15: 946-950.

17. Kebir H, Kreymborg K, Ifergan I, Dodelet-Devillers A, Cayrol R, Bernard M et al. Human TH17 lymphocytes promote blood-brain barrier disruption and central nervous system inflammation. Nat Med 2007; 13: 1173-1175.

18. Hendrix $\mathrm{S}$, Nitsch $\mathrm{R}$. The role of $\mathrm{T}$ helper cells in neuroprotection and regeneration. J Neuroimmunol 2007; 184: 100-112.

19. Ishii $H$, Kubo T, Kumanogoh A, Yamashita $T$. Th1 cells promote neurite outgrowth from cortical neurons via a mechanism dependent on semaphorins. Biochem Biophys Res Commun 2010; 402: 168-172.

20. Zhang $P$, Smith R, Chapkin RS, McMurray DN. Dietary (n-3) polyunsaturated fatty acids modulate murine Th1/Th2 balance toward the Th2 pole by suppression of Th1 development. J Nutr 2005; 135: 1745-1751.

21. O'Garra A, Murphy K. Role of cytokines in determining T-lymphocyte function. Curr Opin Immunol 1994; 6: 458-466.

22. Wurster AL, Rodgers VL, Satoskar AR, Whitters MJ, Young DA, Collins M et al. Interleukin 21 is a T helper (Th) cell 2 cytokine that specifically inhibits the differentiation of naive Th cells into interferon gamma-producing Th1 cells. J Exp Med 2002; 196: 969-977.

23. Jäger A, Dardalhon V, Sobel RA, Bettelli E, Kuchroo VK et al. Th1, Th17, and Th9 effector cells induce experimental autoimmune encephalomyelitis with different pathological phenotypes. J Immunol 2009; 183: 7169-7177.

24. Laurence A, Tato CM, Davidson TS, Kanno Y, Chen Z, Yao Z et al. Interleukin-2 signaling via STAT5 constrains T helper 17 cell generation. Immunity 2007; 26: 371-381.

25. Kim JE, Liu BP, Park JH, Strittmatter SM. Nogo-66 receptor prevents raphespinal and rubrospinal axon regeneration and limits functional recovery from spinal cord injury. Neuron 2004; 44: 439-451.

26. Butovsky O, Landa G, Kunis G, Ziv Y, Avidan H, Greenberg N et al. Induction and blockage of oligodendrogenesis by differently activated microglia in an animal model of multiple sclerosis. J Clin Invest 2006; 116: 905-915.

27. Shechter R, London A, Varol C, Raposo C, Cusimano M, Yovel G et al. Infiltrating bloodderived macrophages are vital cells playing an anti-inflammatory role in recovery from spinal cord injury in mice. PLoS Med 2009; 6: e1000113.

28. Kigerl KA, Gensel JC, Ankeny DP, Alexander JK, Donnelly DJ, Popovich PG. Identification of two distinct macrophage subsets with divergent effects causing either neurotoxicity or regeneration in the injured mouse spinal cord. J Neurosci 2009; 29: 13435-13444.

29. David S, Kroner A. Repertoire of microglial and macrophage responses after spinal cord injury. Nat Rev Neurosci 2011; 12: 388-399.

30. Saraiva M, Christensen JR, Veldhoen M, Murphy TL, Murphy KM, O'Garra A. Interleukin10 production by Th1 cells requires interleukin-12-induced STAT4 transcription factor and ERK MAP kinase activation by high antigen dose. Immunity 2007; 31: 209-219.

31. Rossignol S, Schwab M, Schwartz M, Fehlings MG. Spinal cord injury: time to move? J Neurosci 2007; 27: 11782-11792.

32. Kotter MR, Setzu A, Sim FJ, Van Rooijen N, Franklin RJ. Macrophage depletion impairs oligodendrocyte remyelination following lysolecithin-induced demyelination. Glia 2001; 35 : 204-212.

33. Butovsky O, Ziv Y, Schwartz A, Landa G, Talpalar AE, Pluchino S. Microglia activated by IL-4 or IFN-gamma differentially induce neurogenesis and oligodendrogenesis from adult stem/progenitor cells. Mol Cell Neurosci 2006; 31: 149-160.

34. Engesser-Cesar C, Anderson AJ, Basso DM, Edgerton VR, Cotman CW. Voluntary wheel running improves recovery from a moderate spinal cord injury. J Neurotrauma 2005; 22: 157-171.

35. Basso DM, Fisher LC, Anderson AJ, Jakeman LB, McTigue DM, Popovich PG. Basso Mouse Scale for locomotion detects differences in recovery after spinal cord injury in five common mouse strains. J Neurotrauma 2006; 23: 635-659.

36. Rivlin AS, Tator $\mathrm{CH}$. Objective clinical assessment of motor function after experimental spinal cord injury in the rat. J Neurosurg 1977; 47: 577-581.

37. Fehlings $M G$, Tator $\mathrm{CH}$. The relationships among the severity of spinal cord injury, residual neurological function, axon counts, and counts of retrogradely labeled neurons after experimental spinal cord injury. Exp Neurol 1995; 132: 220-228.

38. Sundberg LM, Herrera JJ, Narayana PA. In vivo longitudinal MRI and behavioral studies in experimental spinal cord injury. J Neurotrauma 2010; 10: 1753-1767.

39. Fuchs PN, Roza C, Sora I, Uhl G, Raja SN. Characterization of mechanical withdrawal responses and effects of mu-, delta- and kappa-opioid agonists in normal and mu-opioid receptor knockout mice. Brain Res 1999; 821: 480-486.

40. Serada S, Fujimoto M, Mihara M, Koike N, Ohsugi Y, Nomura S et al. IL-6 blockade inhibits the induction of myelin antigen-specific Th17 cells and Th1 cells in experimental autoimmune encephalomyelitis. Proc Natl Acad Sci USA 2008; 105: 9041-9046.

Cell Death and Disease is an open-access journal published by Nature Publishing Group. This work is licensed under the Creative Commons Attribution-NonCommercialShare Alike 3.0 Unported License. To view a copy of this license, visit http://creativecommons.org/licenses/by-nc-sa/3.0/ 